\title{
CERAMIC MATRIX COMPOSITE VANE SUBELEMENT TESTING IN A GAS TURBINE ENVIRONMENT
}

\author{
Michael Verrilli and Anthony Calomino \\ NASA Glenn Research Center, Cleveland, Ohio, USA \\ R. Craig Robinson \\ QSS Group, NASA Glenn Research Center, Cleveland, Ohio, USA \\ David J. Thomas \\ OAI, Brookpark, Ohio, USA
}

\begin{abstract}
Vane subelements were fabricated from a silicon carbide fiber reinforced silicon carbide matrix $(\mathrm{SiC} / \mathrm{SiC})$ composite and were coated with an environmental barrier coating (EBC). A test configuration for the vanes in a gas turbine environment was designed and fabricated. Prior to testing, finite element analyses were performed to predict the temperatures and stress conditions present in vane during rig testing. This paper discusses the test configuration, the finite element analysis predictions, and results of the vane testing.
\end{abstract}

\section{INTRODUCTION}

Ceramics are being evaluated for hot sections of advanced turbine engines due to potential improved performance, such as lower emissions and higher cycle efficiency, relative to today's engines with superalloy hot section components. Several recent efforts focused on development of monolithic ceramics for airfoil applications, such as $\mathrm{Si}_{3} \mathrm{~N}_{4}$ [1-2] and cast eutectic ceramics [3]. A recent study demonstrated fabrication of an exhaust guide vane from a $\mathrm{SiC} / \mathrm{SiC}$ composite having $3 \mathrm{D}$ fiber architecture [4]. These stationary airfoils are intended for use as combustor exhaust guide vanes, which turn the hot gas flow path normal to the first stage turbine blades.

The capability of a ceramic matrix composite (CMC), such as $\mathrm{SiC} / \mathrm{SiC}$, for use as combustor liners has been demonstrated [5-7]. CMC's are more damage tolerant than monolithic ceramics, particularly under impact conditions [8], and thus may be better suited for demanding turbine airfoil applications. However, the lower strength of CMC's relative to the superalloys currently used in airfoil applications, and the complexity of interfacing ceramic components with metal hardware within the engine [1,5] present challenges to a turbine designer. Also, it is difficult to fabricate components with small radii using the stiff stoichiometric $\mathrm{SiC}$ fibers currently preferred for high temperature-capable $\mathrm{SiC} / \mathrm{SiC}$ composites.
The objective of this research was to demonstrate the scale up of the $\mathrm{SiC} / \mathrm{SiC}$ material system from the panels and simple component architectures previously produced to the more complex architecture of a turbine vane. The $\mathrm{SiC} / \mathrm{SiC}$ material used in this activity was developed under NASA's Enabling Propulsion Materials and Ultra Efficient Engine Technologies programs [9-11]. Included in this activity was the development of a unique SiC fiber architecture for the vane's sharp trailing edge, fabrication of two $\mathrm{SiC} / \mathrm{SiC}$ prototypical vane designs, development of an advanced environmental barrier coating (EBC) for airfoils, and rig testing in a turbine environment. The details of composite vane subelement fabrication are described elsewhere [12]. This paper discusses the rig test configuration, analyses of the vanes during rig testing, and test results for the $\mathrm{SiC} / \mathrm{SiC}$ vane subelements.

\section{VANE GEOMETRY AND MATERIAL}

Turbine vanes used in modern engines typically have sharp trailing edges and blunt leading edges. A typical vane has a cross section that is not constant along its axial direction. Our objective was to fabricate a vane structure from a $\mathrm{SiC} / \mathrm{SiC}$ ceramic composite that has a relevant geometry to actual engine hardware. Therefore, a cross-sectional slice of an aircraft engine metal vane was the basis of our vane subelement geometry, as shown in Figure 1. The vane subelement tested in this study had this constant cross-section, with a trailing edge radius of $0.3 \mathrm{~mm}$, a wall thickness of $1.5 \mathrm{~mm}$, a leading edge radius of $3.1 \mathrm{~mm}$, and was $50 \mathrm{~mm}$ in height.

The vane subelement consisted of six plies of Sylramic ${ }^{\mathrm{TM}}$ $\mathrm{SiC}$ fiber cloth reinforced with a CVI/slurry-cast/melt infiltrated $\mathrm{SiC} / \mathrm{Si}$ matrix. A unique 2D cloth configuration, termed Y-cloth, was developed to enable through-thickness fiber reinforcement in the sharp trailing edge of the vane. More details regarding the vane fabrication are given in reference 12 . 
To protect the $\mathrm{SiC} / \mathrm{SiC}$ substrate from recession in the turbine environment, an environmental barrier coating (EBC) was applied to the vanes. The coating system consisted of a silicon bond coat, a mullite intermediate coat, and a proprietary rare earth silicate topcoat. A coated $\mathrm{SiC} / \mathrm{SiC}$ vane subelement is shown in Figure 2. Cooling holes were machined in the trailing edge via laser drilling prior to application of the EBC.

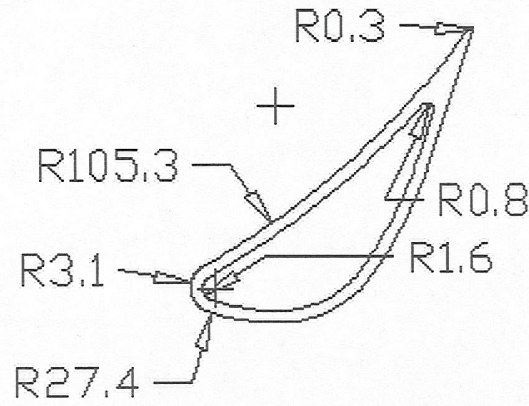

Figure 1 - Geometry of vane subelement. Dimensions are in mm.

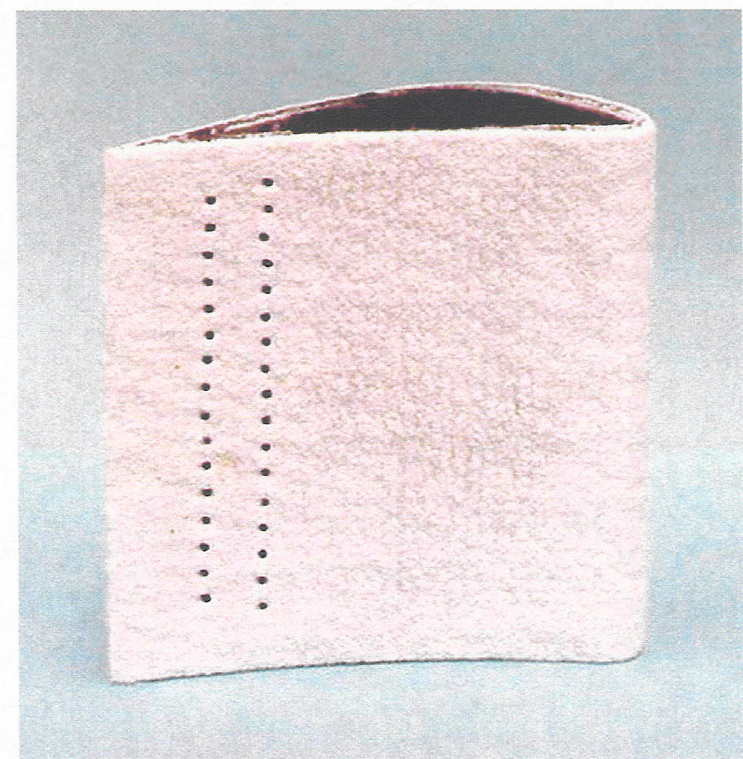

Figure 2 - As-fabricated $\mathrm{SiC} / \mathrm{SiC}$ vane with trailing edge cooling holes and coated with an EBC.

\section{VANE TEST CONFIGURATION}

The test configuration was comprised of three parallel vanes contained in a water-cooled pressure section (Figure 3). The center vane was the $\mathrm{SiC} / \mathrm{SiC}$ test specimen with Haynes 188 superalloy vanes on either side to help establish flow around the $\mathrm{SiC} / \mathrm{SiC}$ vane. The three vanes had the same external geometry and were held in place using superalloy platforms as shown in Figure 4 but were not mechanically attached to the platforms. Vane cooling air flowed through these superalloy plates into both ends of the vanes and out through holes in the trailing edge for all three components. The test section design enabled gas temperature measurement adjacent to the vanes via a thermocouple. Optical pyrometry was used to measure external vane material temperatures (Figure 3). Also, thermocouples were installed downstream of the vane test section to measure gas temperatures. The assembled test fixture is shown in Figure 5.

\section{RIG DESCRIPTION}

The $\mathrm{SiC} / \mathrm{SiC}$ vanes were tested using NASA's High Pressure Burner Rig (HPBR), shown in Figure 6. The rig burns jet fuel and enables material specimens and components to be exposed to pressures of 4 to $15 \mathrm{~atm}$ and gas velocities of 10 to $30 \mathrm{~m} / \mathrm{sec}$, under either lean-burn or rich-burn combustion mixtures [13]. Flow from the combustor was directed from the $150 \mathrm{~mm}$ inner diameter rig flow duct to the $50 \mathrm{~mm}$ high by 100 mm wide vane test section using a transition duct (Figure 3). The transition duct was fabricated from a HiNicalon ${ }^{\mathrm{TM}}$ fiber reinforced CVI SiC matrix composite and was also coated with an EBC. Another duct fabricated from the same material was placed downstream of the test section to protect the rig structure from directed impingement of hot gases.

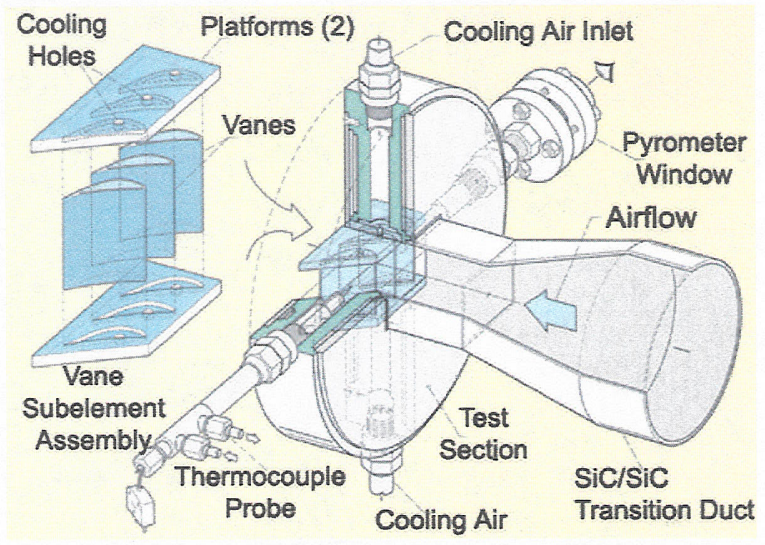

Figure 3 - Test section configuration used for testing of SiC $/$ SiC wanes.

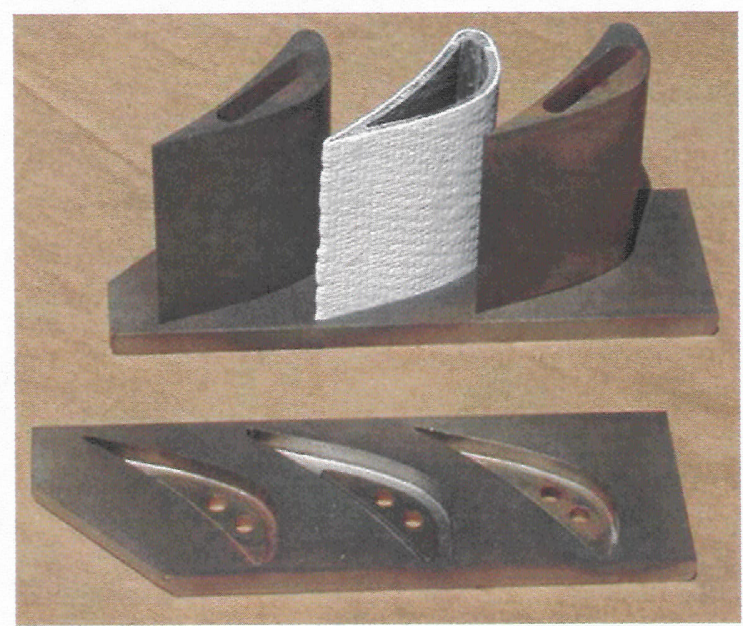

Figure 4 - Vanes in holder prior to testing.

\section{TEST CONDITIONS}

A rig pressure of $6 \mathrm{~atm}$ and combustion flow of $0.5 \mathrm{~kg} / \mathrm{sec}$ was selected for testing of the $\mathrm{SiC} / \mathrm{SiC}$ vane subelements. The gas velocity at the entrance of the vane test section was 60 $\mathrm{m} / \mathrm{sec}$ resulting from the small cross-sectional area of the three 
vanes. An air flow of $0.15 \mathrm{~kg} / \mathrm{sec}$ was used to cool the internal cavities of all vanes in the test section.

The test program consisted of 50 hours of steady state operation (carried out over the course of 9 days) followed by 102 thermal cycles. The cyclic testing was conducted in a single day using a 2-minute cycle. Gas temperature (and ultimately material temperature) was controlled through variation of the combustor's fuel/air ratio under lean mixtures. During the 2-minute cycle, the gas temperature was held at a constant minimum value for 45 seconds, then heated to a maximum over 15 seconds, held for 45 seconds, and finally cooled back to the minimum temperature in 15 seconds. The minimum gas temperatures ranged from 900 to $1050{ }^{\circ} \mathrm{C}$ and maximum temperature ranged from 940 to $1440{ }^{\circ} \mathrm{C}$.

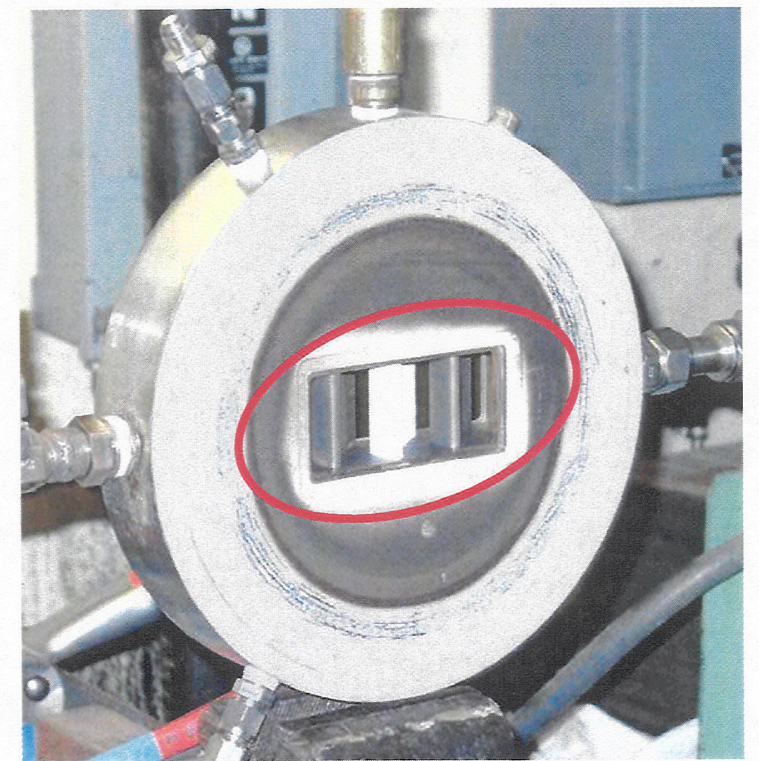

Figure $5-$ Vane subelements installed in the test section.

\section{ANALYSES OF VANE DURING RIG TESTING}

Prior to testing, computational fluid dynamics (CFD) and finite element (FE) analyses were performed to predict the temperature and stress conditions present in the vane during rig testing. Analyses were performed for a preliminary vane design that did not include trailing edge cooling. An updated model including cooling holes is currently being analyzed. The CFD analysis for a cascade of blades was performed using a two-dimensional Euler (i.e., inviscid flow) equation solver. Local pressure and velocity results were used to determine heat transfer coefficients for the vanes exterior surface. Internal cooling of the vane was modeled as constant $93^{\circ} \mathrm{C}$ air flowing axially through the vane cavity at a rate of $0.15 \mathrm{~kg} / \mathrm{sec}$. The convection coefficient was modeled as turbulent flow through a non-circular tube The predicted maximum temperature (1190 ${ }^{\circ} \mathrm{C}$ ) was within the material capabilities based on coupon rupture life $\left(\sim 1300^{\circ} \mathrm{C}\right)$. Calculated in-plane tensile stresses were low (maximum axial stress of $27 \mathrm{MPa}$ and maximum transverse or "hoop" stress of $105 \mathrm{MPa}$ ), but the interlaminar tensile (ILT) stresses predicted were found to be high enough to be of concern. ILT values in the leading edge (14 MPa) occur over a rather large area (see Fig. 7) and approach the flat panel measured strength value $(17 \mathrm{MPa})$ for this material. In the

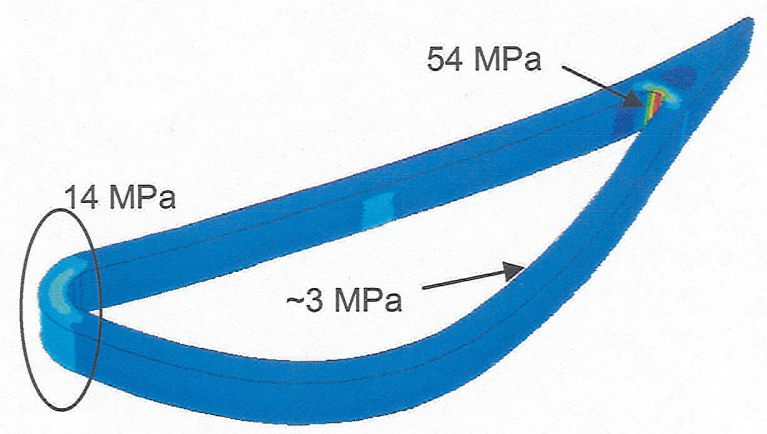

Figure 7 - Interlaminar tensile stresses predicted for the $\mathrm{SiC} / \mathrm{SiC}$ vane subelement during rig testing.

vane's the trailing edge, the ILT values (54 MPa) exceeded the measured strength. Figure 8 shows the approach that was used for modeling the local material orientations within the vane. For purposes of modeling, the trailing edge region was segmented into pressure side and suction side "wedges." All elements within each wedge were assigned a material orientation aligned with the plane of the segments outer surface. This closely approximates the actual architecture within the Y-cloth region, however it also leads to a material property discontinuity at the inside fillet radius. As a result,

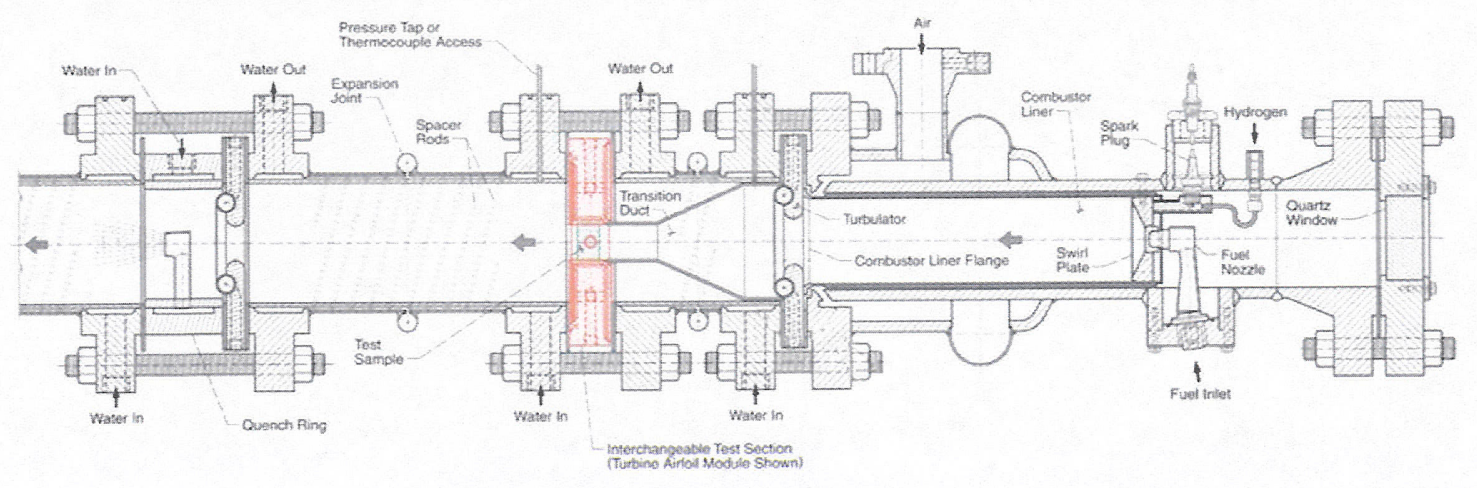

Figure 6 - Configuration of NASA's High Pressure Burner Rig . 
these stresses are artificially inflated in this analysis. Considering this in combination with the facts that the stress is very localized and that the vane's y-cloth architecture provides through thickness fiber reinforcement at the trailing edge, these trailing edge stresses were considered less of a concern than those at the leading edge.

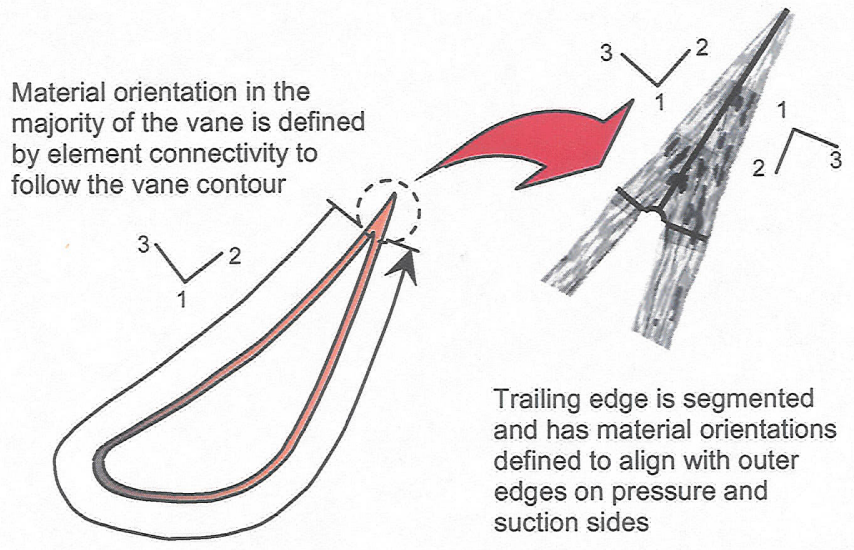

Figure 8 - Modeling of material orientations.

\section{RESULTS}

Typical temperature measurements obtained during rig testing of the vane are shown in Figure 9. Data shown here was obtained during the $18^{\text {th }}$ hour of steady state testing. The gas temperature adjacent to one of the superalloy vanes reached $1100{ }^{\circ} \mathrm{C}$ and the surface temperature of the other superalloy vane peaked at $1180^{\circ} \mathrm{C}$. Gas temperatures of 1150 to $1200^{\circ} \mathrm{C}$ were measured downstream of the vanes. After completion of 20 hours of testing, the $\mathrm{SiC} / \mathrm{SiC}$ vane subelement had no visual degradation, whereas the superalloy vanes and other superalloy rig hardware had visually identifiable cracks.

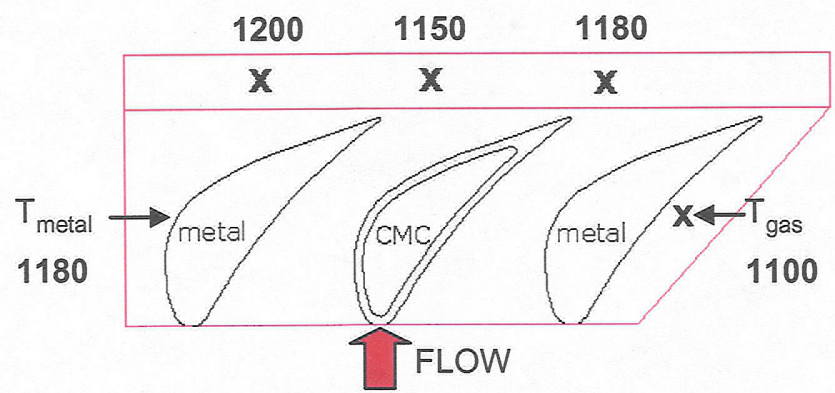

Figure 9 - Temperatures $\left({ }^{\circ} \mathrm{C}\right)$ measured during steady state testing of $\mathrm{SiC} / \mathrm{SiC}$ vane subelement.

To allow measurement of the $\mathrm{SiC} / \mathrm{SiC}$ vane temperature using optical pyrometry, one superalloy vane was removed to permit a proper sight line and testing was continued. As shown in Figure 10, the peak surface (EBC) temperature of the $\mathrm{SiC} / \mathrm{SiC}$ vane subelement was $1170^{\circ} \mathrm{C}$. For both the two-vane and three-vane test configurations, rig operating conditions were held constant and similar gas temperatures were obtained (the exception was the cooler downstream temperature at the rig centerline). After 8 hours in the two-vane configuration, the third vane was re-introduced for the duration of the 50 hours of steady state operation. Also, no damage of the CMC vane was observed.

The rig was disassembled to inspect the test section after completion of 50 hours of testing. Water was found in the test section. One of the water-cooled thermocouples downstream of the test section was found to have leaked prior to the beginning of the last 3.5 hours of testing. This lead to the accumulation of water in the test section between rig runs. During this period of time, the $\mathrm{SiC} / \mathrm{SiC}$ vane absorbed some of this water. Upon restarting the test, the absorbed water vaporized, producing spallation damage (Figure 11). About $26 \%$ of the total coating surface area had spalled. NDE inspection via computed tomography revealed regions of spalled surface composite ply as well.

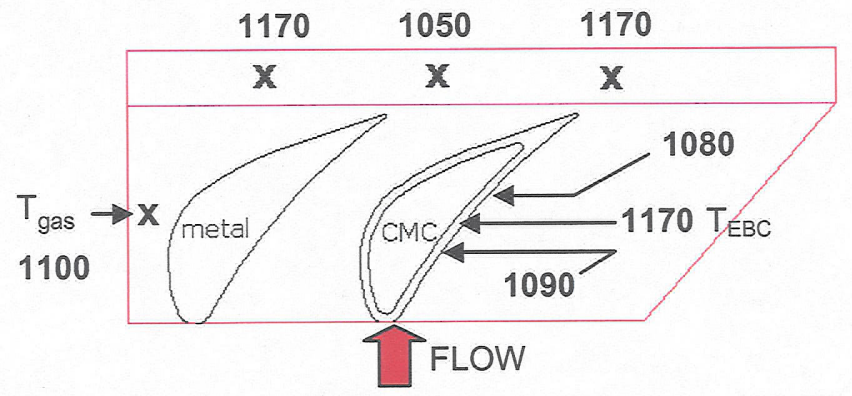

Figure 10 - Temperatures $\left({ }^{\circ} \mathrm{C}\right)$ measured during steady state testing of $\mathrm{SiC} / \mathrm{SiC}$ vane subelement. One superalloy vane was removed to enable measurement of $\mathrm{SiC} / \mathrm{SiC}$ vane temperature.

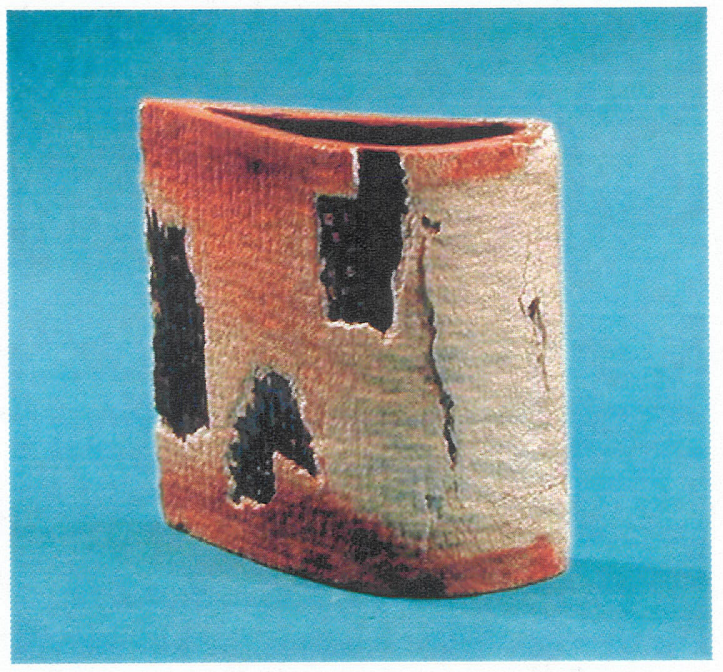

Figure 11 - SiC/SiC vane (number 909) after inadvertent water exposure followed by rig testing for 3.5 hours.

A second EBC-coated $\mathrm{SiC} / \mathrm{SiC}$ vane subelement was prepared for the cyclic testing phase of the program. The twominute cycle previously described was employed. As with the steady state testing, the lack of line of sight to the $\mathrm{SiC} / \mathrm{SiC}$ vane hindered temperature readings of the vane subelement's surface. To remedy this, a $20 \mathrm{~mm}$ hole was drilled in one of the 
superalloy vanes, providing a direct optical path for the pyrometer. This metallic vane had no cooling holes.

As stated earlier, cracks formed in the superalloy vane holders and the superalloy vanes due to high material temperatures and long exposures during the steady state testing. However, during the cyclic testing, the shorter dwell time at peak temperatures was expected to minimize overheating of these metallic parts. Initial minimum and maximum gas temperatures were thus selected based on experience gained during the steady state testing. However, one goal was to reach a material temperature of at least $1300{ }^{\circ} \mathrm{C}$. Therefore, the gas temperatures were incrementally increased through step changes of the cycle to obtain this material temperature.

Considerably higher gas and material temperatures were reached during the cyclic peaks than had been obtained during the steady state testing (Figure 12). The EBC surface temperature reached $1320^{\circ} \mathrm{C}$ and the maximum test section gas temperature for this cycle was $1400^{\circ} \mathrm{C}$.

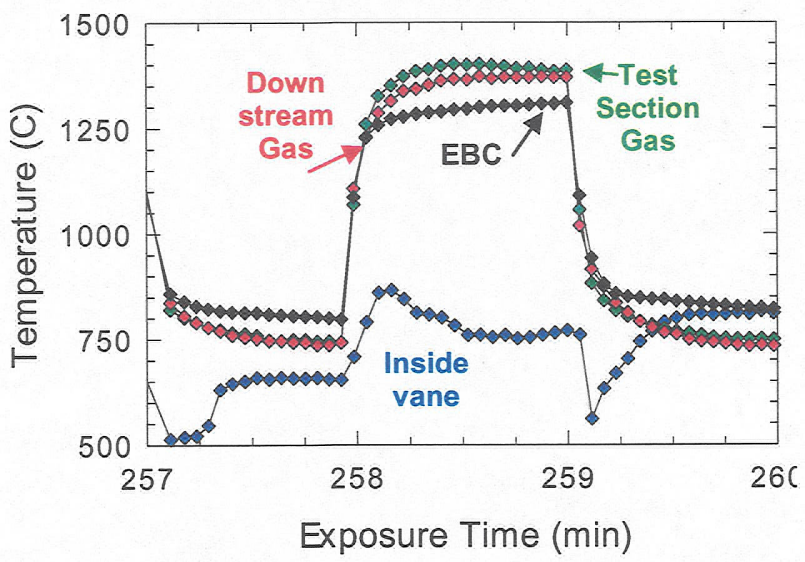

Figure 12 - Temperatures measured during cycle 100.

Inspection of the test section after 102 thermal cycles revealed considerable damage of the test section metal hardware. Melting of the superalloy vanes occurred, as well as other test section metal hardware. The $\mathrm{SiC} / \mathrm{SiC}$ vane subelement was intact but had deposits on the EBC surface (Fig. 13). X-ray diffraction revealed evidence of the Co-based Haynes 188 vane on the suction side of the $\mathrm{SiC} / \mathrm{SiC}$ vanes, (which can be seen in Fig. 12) and deposits of Ni-based Waspaloy on the pressure side. Note that both these alloys melt above $1400{ }^{\circ} \mathrm{C}$. Using the computed tomography NDE technique, no damage of this $\mathrm{SiC} / \mathrm{SiC}$ vane was found.

Both $\mathrm{SiC} / \mathrm{SiC}$ vanes were sliced at the midline to obtain sections for microstructural examination. A slice from each vane was mounted in florescent epoxy and polished.

Prior to sectioning, the coating was removed from the vane tested under steady state conditions (vane 909) in order to potentially re-coat it for further testing. However, since the visual and NDE inspection revealed composite surface damage, a second vane (number 910) was selected for the cyclic testing. Thus, coating microstructure of the first vane was not available, only that of the substrate. The second vane (910) was mounted in the as-tested condition.
The cross sections of both vanes are shown in Figure 14 Engineering drawings of the inside and outside vane nominal profile are superimposed over the micrographs of the vanes. Both vanes retained their shape even after exposure to severe test conditions. Cooling holes can be seen near the trailing edges of both vanes, and excess matrix is evident near the leading edge of vane 909 , on the inside surface.

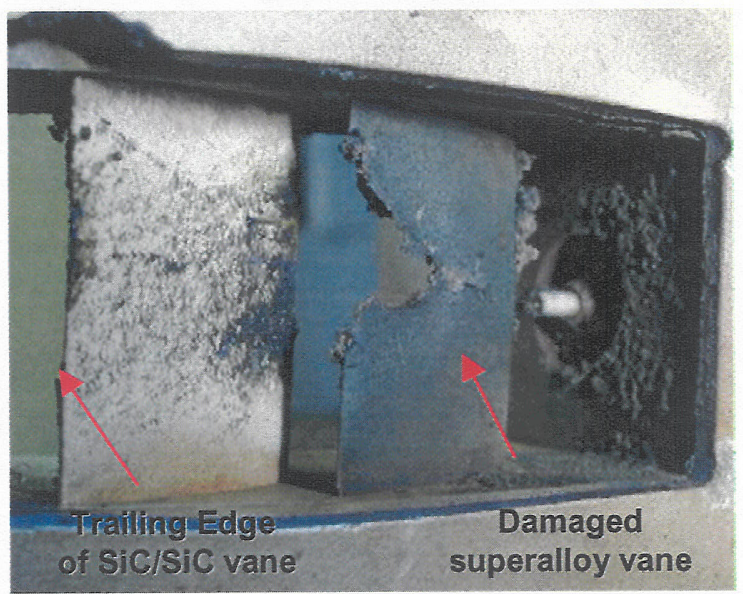

Figure 13 - SiC/SiC (number 910) and superalloy vane subelements after the cyclic testing.

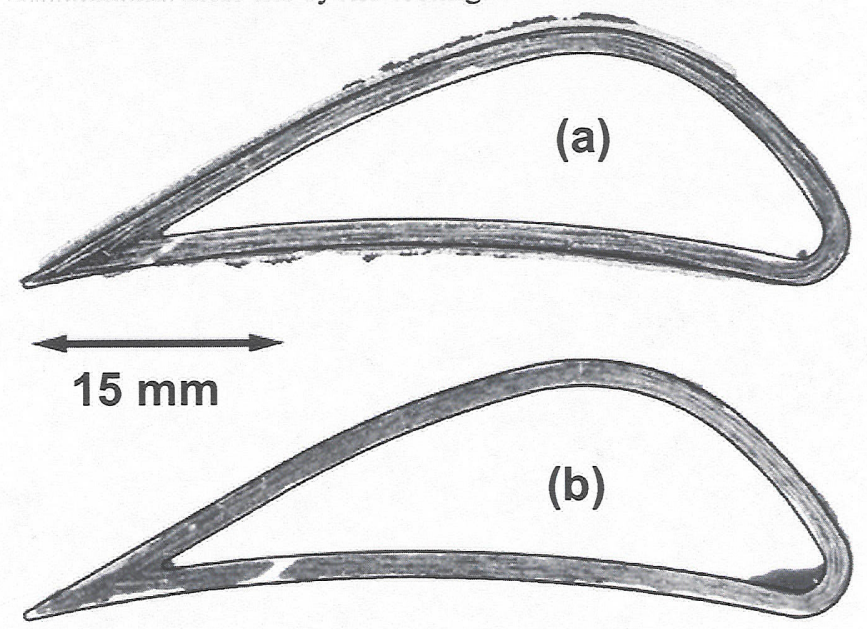

Figure 14 - Cross sections of $\mathrm{SiC} / \mathrm{SiC}$ vanes after rig testing, (a) vane 910 tested under cyclic conditions, (b) vane 909 tested under steady state conditions.

Since the finite element analyses predicted the highest stresses to exist in the leading and trailing edges, it is important to examine the microstructure in these regions. In Figure 15, details of the leading edges are shown. A coating of superalloy exists on vane 910 on both the pressure and suction sides. This coating starts in a location that is about $7 \mathrm{~mm}$ away from the leading edge (as measured along the bottom surface in the Fig. 15 (a) or the pressure side of the vane). Spallation of outer composite plies exists in vane 909 at locations away from the leading edge. However, no cracks exist. In both vanes, the gap on the ID between the actual vane profile and the drawing near the leading edge are the result of the manufacturing process. 
Details of the trailing edge microstructures (Figure 16) revealed features similar to those seen in the leading edge. Superalloy deposits of about $0.4 \mathrm{~mm}$ thickness extend toward the trailing edge radius in vane 910 . Composite ply spallation and a crack are visible near the trailing edge of vane 909 . The outer ply is missing near the cooling hole while three outer plies spalled off in the most damaged regions. It is likely that this spallation, which occurred during rig start up, resulted in higher stresses in the trailing edge of vane 909 during subsequent rig operation, leading to the crack. In spite of this damage, the trailing edge of vane 909 remained intact. Additional microstructural analyses of both $\mathrm{SiC} / \mathrm{SiC}$ vane subelements are in progress.
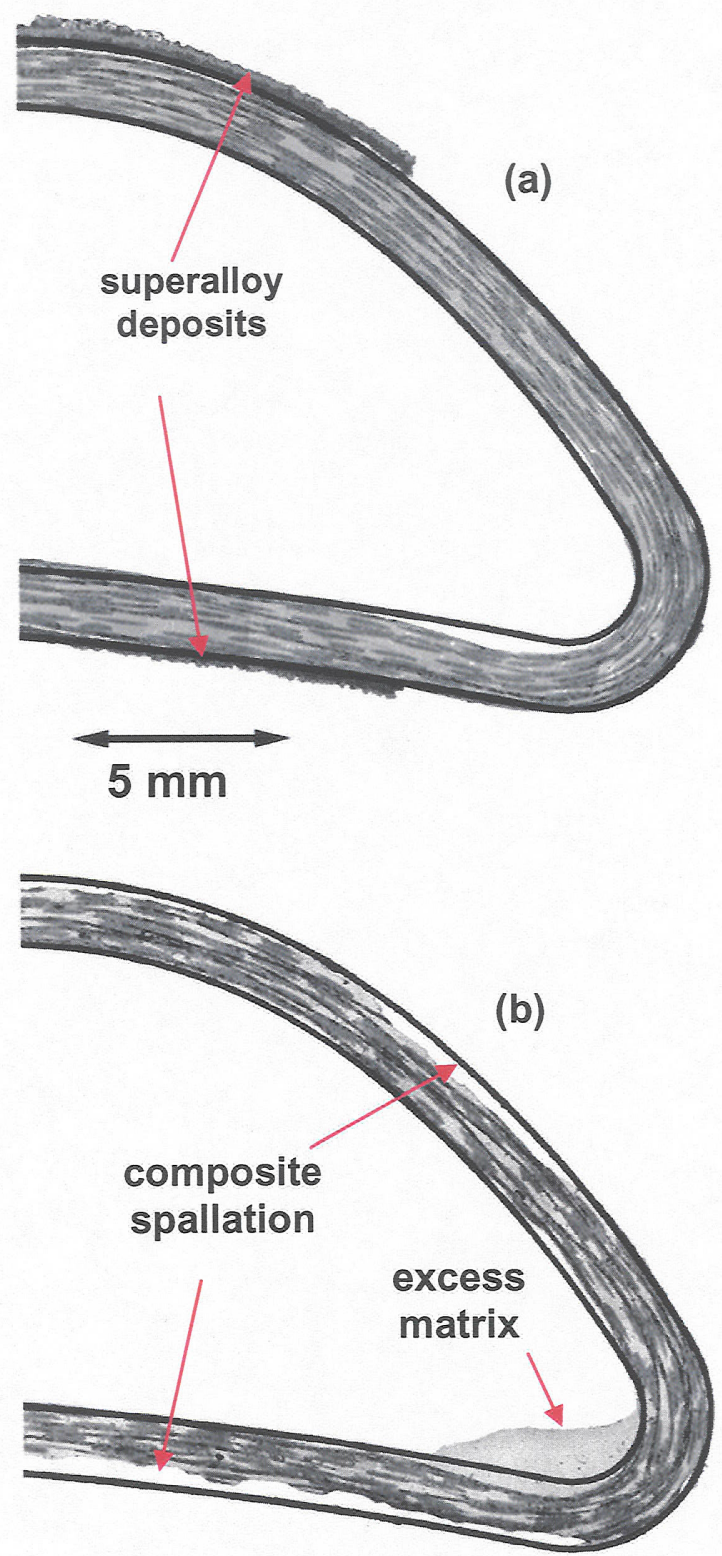

Figure 15 - Microstructure of the leading edge of $\mathrm{SiC} / \mathrm{SiC}$ vanes subelements after rig testing, a) vane 910 tested under cyclic conditions, (b) vane 909 tested under steady state conditions.

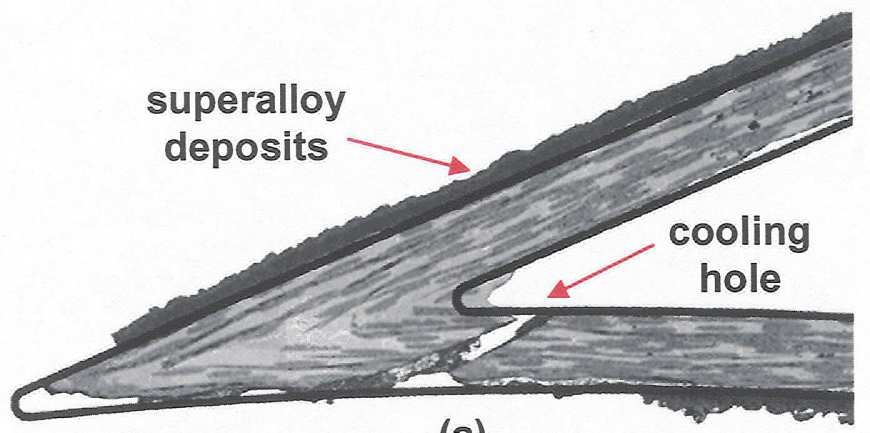

(a)

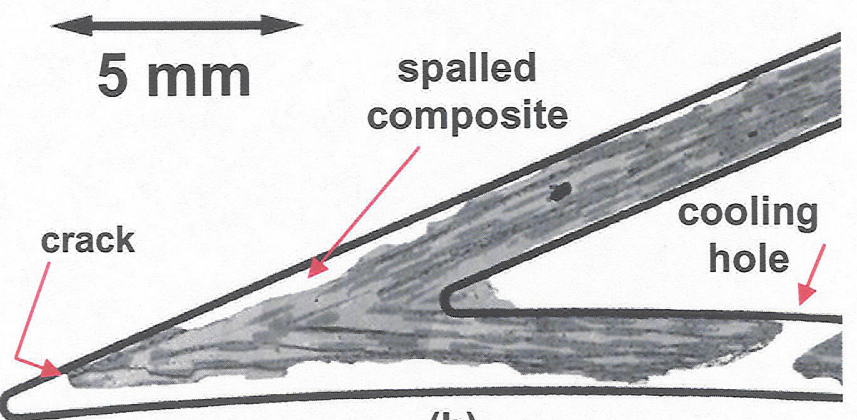

(b)

Figure 16 - Microstructure of the trailing edge of $\mathrm{SiC} / \mathrm{SiC}$ vanes subelements after rig testing, a) vane 910 tested under cyclic conditions, (b) vane 909 tested under steady state conditions.

\section{SUMMARY AND CONCLUSIONS}

Vane subelements were fabricated from a $\mathrm{SiC} / \mathrm{SiC}$ composite and were tested in a turbine environment. Testing consisted of fifty hours of steady state operation and 1022 minute thermal cycles. A surface temperature of $1300^{\circ} \mathrm{C}$ was obtained for the $\mathrm{EBC}$ coated $\mathrm{SiC} / \mathrm{SiC}$ vane subelement. The vanes were inadvertently subjected to extremely severe test conditions (such as exposure to standing water prior to combustion exposure and deposition of molten superalloy parts) which lead to damage in the vanes. Microstructural examinations revealed the extent of spallation in one vane due to vaporization of absorbed water, and deposition of molten metal on both the pressure and suction sides of the second vane. Both vanes retained their shape even after exposure to these severe test conditions and they maintained full functionality. These encouraging results show the potential of $\mathrm{SiC} / \mathrm{SiC}$ composites for turbine airfoil applications.

\section{ACKNOWLEDGEMENT}

The authors like to thank NASA's Ultra Efficient Engine Technology (UEET) program for sponsoring this research.

\section{REFERENCES}

[1] Jimenez, O., Bagheri, H., McClain, J., Ridler, K., and Bornemisza, T., "CSGT: Final Design and Test of a Ceramic Hot Section" in the proceedings of Turbo Expo 2003: ASME Turbo Expo, Land, Sea \& Air, June 16-19, 2003, Atlanta, Georgia, USA, ASME paper GT2003-38978. 
[2] Nagata, H., Karaswa, W., Ichikawa, Y., Tsuruzono, S., and Fukudome, T., "Development of the $8000 \mathrm{KW}$ Class Hybrid Gas Turbine", in the proceedings of Turbo Expo 2003: ASME Turbo Expo, Land, Sea \& Air, June 16-19, 2003, Atlanta, Georgia, USA, ASME paper GT2003-38703.

[3] Fuijwara, K., Nakagawa, N., Kobayashi, K., Yokoi, S., Kihara, T., and Takamatsu, H., "Research on Application of Melt-Growth Composite Ceramics to Gas Turbines" in the proceedings of Turbo Expo 2003: ASME Turbo Expo, Land, Sea \& Air, June 16-19, 2003, Atlanta, Georgia, USA, ASME paper GT2003-38029.

[4] Watanbe, K., Suzumura, N., Nakamura, T., Murata, H., Araki, T., and Natsumura, T., "Development of CMC Vane for Gas Turbine Engine", Ceramic Engineering and Science Proceedings, Vol. 24, Issue 4, 2003, pp. 599-604.

[5] Brewer, D., Ojard, G., and Gibler, M., "Ceramic Matrix Composite Combustor Liner Rig Test" in the proceedings of Turbo Expo 2000: ASME Turbo Expo, Land, Sea \& Air, May 8-11, 2000, Munich, Germany, paper TE00CER03-03, May, 2000 .

[6] Kimmel, J., Price, J., More, K., Tortorelli, P., Sun, E., and Linsey, G., "The Evaluation of CFCC Liners After Field Testing in a Gas Turbine - IV" in the proceedings of Turbo Expo 2003: ASME Turbo Expo, Land, Sea \& Air, June 16-19, 2003, Atlanta, Georgia, USA, ASME paper GT2003-38920.

[7] Corman, G. S., Dean, A .J., Brabetz, S., Brun, M. K., Luthra, K., Tognarelli, L., and Pecchioli, M., "Rig and Engine Testing of Melt Infiltrated Ceramic Composites for Combustor and Shroud Applications" in the proceedings of Turbo Expo 2000: ASME Turbo Expo, Land, Sea \& Air, May 8-11, 2000, Munich, Germany, paper 2000-GT-638, May, 2000.

[8] van Roode, M., Jimenez, O., McClain, J., Price, J., Poormon, K., Parthasarathy, V., Ferber, M., and Lin, H.T., "Ceramic Gas Turbine Materials Impact Evaluation" in the proceedings of Turbo Expo 2002: ASME Turbo Expo, Land, Sea \& Air, June 16-19, 2002, Amsterdam, the Netherlands, ASME paper GT2002-30505.

[9] Brewer, D., "HSR/EPM Combustion Materials Development Program", Materials Science and Engineering, A261, pp. 284-291, 1999.

[10] Bhatt, R. T., McCue, T. R., and DiCarlo, J. A., "Thermal Stability of Melt Infiltrated SiC/SiC Composites", Ceramic Engineering and Science Proceedings, Vol. 24, Issue 4, 2003, pp. 295-300.

[11] Yun, H. M, DiCarlo, J. A., Bhatt, R. T., and Hurst, J. B., "Processing and Structural Advantages of the Sylramic-iBN Fiber for SiC/SiC Composites", Ceramic Engineering and Science Proceedings, Vol. 24, Issue 4, 2003, pp. 247-254.
[12] Calomino, A., Verrilli, M. J., "Ceramic Matrix Composite Vane Subelement Fabrication" to be published in the proceedings of Turbo Expo 2004: ASME Turbo Expo, Land, Sea \& Air, June 14-17, 2004, Vienna, Austria, ASME paper GT2004-53974.

[13] Robinson, R. C., "NASA GRC's High Pressure Burner Rig Facility and Materials Test Capabilities", NASA CR-1999209411, December 1999. 